LFull title:

\title{
How does land management contribute to the resilience of Mediterranean forests and rangelands? A participatory assessment
}

Short title:

PARTICIPATORY ASSESSMENT OF RESILIENCE IN MEDITERRANEAN ECOSYSTEMS

Authors:

Jucker Riva Matteo ${ }^{1,2, *}$, Baeza Jaime ${ }^{3}$, Bautista Susana ${ }^{4}$, Christoforou Michalakis ${ }^{5}$, Daliakopoulos Ioannis N. ${ }^{6}$, Hadjimitsis Diofantos ${ }^{5}$, Keizer Jan Jacob ${ }^{7}$, Liniger Hanspeter ${ }^{1,2}$, Quaranta Giovanni ${ }^{8}$, Ribeiro Cristina ${ }^{7}$, Salvia Rosanna ${ }^{8}$, Tsanis Ioannis $\mathrm{K}^{6}$., Urgeghe Anna M. ${ }^{4}$, Valdecantos Alejandro ${ }^{3}$, Schwilch Gudrun ${ }^{1}$

${ }^{1}$ Centre for Development and Environment, University of Bern, Switzerland

${ }^{2}$ Institute of Integrative Geography, University of Bern, Switzerland

${ }^{3}$ Mediterranean Centre for Environmental Studies (Foundation CEAM), Spain

${ }^{4}$ Department of Ecology and IMEM, University of Alicante, Spain

${ }^{5}$ Department of Civil Engineering and Geomatics, Cyprus University of Technology, Cyprus

${ }^{6}$ School of Environmental Engineering, Technical University of Crete, Greece

${ }^{7}$ Centre for Environmental and Marine Studies, Dept. of Environment and Planning, University of Aveiro, Portugal

${ }^{8}$ Department of Mathematics, Computer Science and Economics, University of Basilicata, Italy

* Corresponding author: University of Bern, Centre for Development and Environment (CDE), Hallerstrasse 10, 3012 Bern (Switzerland). Phone: +41 3163188 22, matteo.jucker@cde.unibe.ch;

This article has been accepted for publication and undergone full peer review but has not been through the copyediting, typesetting, pagination and proofreading process which may lead to differences between this version and the Version of Record. Please cite this article as doi: $10.1002 / l d r .3104$ 


\section{Abstract}

In Mediterranean forests and rangelands, the supply of important ecosystem services can decrease or cease as a consequence of disturbances and climatic oscillations. Land managers can sometimes prevent or mitigate the negative effects of disturbances through appropriate land management choices. In this study, we assess the contribution of land management practices (LMPs) to the resilience of eight Mediterranean forests and rangelands to multiple disturbances. The study uses a transdisciplinary approach, involving scientists, land managers, and local administrators. Data about disturbances, ecosystem services, the role of LMPs, and the resistance of LMPs to disturbances are combined using a semi-quantitative index, and analysed to evaluate how the LMPs implemented are suited to the disturbances affecting each study site. Our results indicate that the practices analysed are particularly effective in improving resilience of ecosystems against wildfires and torrential rainfalls. However, droughts are more difficult to address, and the examined practices were heavily affected by their occurrence. Tree planting appears to be highly affected by disturbances. Practices that selectively reduce the amount of vegetation appear to be beneficial in fostering recovery of ecosystems. Our assessment also suggests that it is particularly difficult to increase resilience to droughts and fires simultaneously. Practices that aimed to mitigate the impact of land use did not always prove valuable in terms of resilience. Finally, study sites that included efforts to address disturbances in their management objectives also displayed practices making the biggest contribution to resilience.

\section{Introduction}

Dry Mediterranean ecosystems have a long history of exposure to climatic oscillations and land use changes (Alados et al., 2011; Blondel, 2006; Daliakopoulos et al., 2017; Zdruli, 2014). However, land degradation caused by disturbances affects the supply of ecosystem services, sometimes irreversibly (Baeza et al., 2007; Bowman et al., 2016; Mayor et al., 2016; Santana et al., 2014), with negative consequences for the well-being of land users and for the functioning of the ecosystem at larger scale. For example, low Mediterranean woodlands can shift to shrublands after repeated or intense fires (Baeza et al., 2007; Lozano et al., 2012; Pausas et al., 2008). Droughts can trigger shrub encroachment in grass-dominated pastures, changing not only the economic value of the land but also the water cycle at a larger scale (Caldeira et al., 2015; Folke et al., 2004).

Our study aims at evaluating the contribution of land management practices (LMPs) to the resilience of six Mediterranean rangelands and forests affected by disturbances, using as input information gathered through a knowledge co-creation process. Within the context of this study we define resilience as the ability of a land management system to remain productive and valuable, according to land users' evaluations, by withstanding disturbances or recovering from them. Results are analysed to evaluate whether the combination of LMPs implemented in each study site is appropriate to cope with the disturbances affecting each ecosystem, and to obtain a general indication on how different types of practices can contribute to the resilience of natural and semi-natural ecosystems.

Resilience (Holling, 1973), defined as the capacity of a system to withstand or recover from disturbances, is an important feature of ecosystems and a highly debated topic in recent ecological and socioecological research (Bérard et al., 2011; Bernués et al., 2011; Elmqvist et al., 2003; Kizos et al., 2014; Knox \& Clarke, 2012). Since its first definition, resilience, or lack of, has been related to the inner complexity of ecosystems (Cabel \& Oelofse, 2012; Gunderson, 2000; Walker \& Meyers, 2004); it is the result of the multiple interactions between different processes, and their feedbacks. Resilience of ecosystems, however, can be significantly modified by human activities and their interactions with disturbance events and natural processes (Sporton, 2007). Current scientific knowledge does not view 
resilience as a static property; ecosystems can have multiple equilibrium states (or configurations), each of which has its own stability landscape (Gunderson, 2000; Scheffer et al., 2009; Walker et al., 2004). Moreover, according to the panarchy framework (Walker et al., 2004), each system evolves as a result of the interactions occurring at multiple scales (Davoudi et al., 2012; Groffman et al., 2006). Resilience of ecosystems thus can contribute to the long-term sustainability of socioecological systems, allowing for recovery, adaptation, and transformation in the face of shocks and sudden changes (Domptail et al., 2013). Resilience is also used in social studies and human geography, to refer to the capacity of social structures to cope with disturbances and shocks. While some authors attempt to transfer the ecology-based definition to the human domain, others focus on aspects that are distinctive to human systems, such as learning capacity, agency, and power relations (Wilson, 2017).

Land management is defined as the specific combination of practices through which land is used (Hurni, 2000). It is different from "land use", which is the objective or purpose for which land management is implemented (FAO \& UNEP, 1999) and which refers to broader categories such as cropland, grazing land, or forest land. Land management practices (LMPs) are normally implemented to increase productivity of the land or to reduce degradation associated with human activities. Through land management, humans can also change the resilience of ecosystems (Alados et al., 2011; Crépin et al., 2012; Folke et al., 2010; Jucker Riva et al., 2016): Successful LMPs can make it more difficult for an ecosystem to reach a critical threshold (e.g. reducing the frequency of fires in a forest area prevents a shift to shrub-dominated vegetation). Further, LMPs can reduce the impact of disturbances (e.g. increasing vegetation reduces erosion during torrential rainfall) or directly move the system towards a more stable configuration (e.g. afforestation after a fire in case of failed spontaneous recovery). Adapting LMPs to increase resilience to disturbances - so-called "resilience thinking" (Plummer \& Armitage, 2007; Rist \& Moen, 2013) - is in most cases preferable to changing the land use as a whole, which would require great efforts and have highly uncertain ecological and socioeconomic impacts, possibly affecting the livelihoods of local communities. While a wide set of methods and tools exist to assess how LMPs affect sustainability of land use (Bunning et al., 2011; ELD Initiative, 2015; WOCAT, 2008), there are few studies that focus on how LMPs influence the resilience of ecosystems. The few such studies that exist are very case specific (e.g. valid only for a certain event or area) or context specific (e.g. valid only for a certain type of disturbance). Thus, despite efforts to operationalize the resilience of ecosystems to avoid the loss of ecosystem services (Bergamini et al., 2013; Mitchell et al., 2014; Plummer \& Armitage, 2007; Resilience Alliance, 2010), it remains difficult to identify practical solutions for land managers, as the value of a certain LMP may vary greatly if we consider only the degradation caused by land use or if we include increasing resilience to disturbances within the management objectives (Jucker Riva et al., 2016). Therefore, there is a need to increase our understanding of how LMPs can contribute to resilience. There is also a need for practical methodologies to evaluate the role of land management, to avoid a decrease in resilience and to achieve cost-effective management strategies, thus increasing long-term sustainability.

LMPs are often difficult to assess, as the impact of practices can be extremely diverse even within the same area, depending on the timing, location, and conditions of the environment in which they are implemented (Liniger et al., 2017; Schwilch et al., 2011). Systematic information on the application and impacts of practices is often lacking and difficult to compare. Moreover, the value of LMPs also depends on their economic sustainability and cultural acceptability (Hurni, 2000); thus, the perception of different actors is extremely relevant. Co-creation of knowledge, also known as transdisciplinary research (Hadorn et al., 2006; Mauser et al., 2013; Pohl \& Hirsch Hadorn, 2007; Regeer \& Bunders, 2009), is an innovative approach to address complex environmental issues. It stems from the idea that 
multiple types of knowledge exist beyond conventional science, and that they can be combined (Bautista et al., 2017; Reed et al., 2008; Regeer \& Bunders, 2009; Tabara \& Chabay, 2013). It consists of a process in which scientists from different disciplines and stakeholders actively exchange and combine information on a certain topic. This approach has been applied successfully to the assessment of LMPs in multiple ecosystems around the globe (Liniger et al., 2013; Liniger \& Schwilch, 2002; Pohl et al., 2010; Schneider \& Rist, 2014; Schwilch et al., 2009, 2012, 2013). Not only is the perception of stakeholders considered in the assessment, but also their knowledge and experience about the land is used to contextualize data and fill information gaps that may arise during the assessment. This knowledge co-creation approach is in line with recent approaches to resilience studies (Bergamini et al., 2013; O'Connell et al., 2016; Plummer \& Armitage, 2007; Rist \& Moen, 2013; Sporton, 2007; Walker et al., 2010): the focus is on gathering and combining existing knowledge (Resilience Alliance, 2010), using methodologies based on self-evaluation (Choptiany et al., 2016), participation (Cumming et al., 2005; Dixon \& Stringer, 2015), and/or active exchange between scientists and land managers (Domptail et al., 2013; Mitchell et al., 2014). Finally, the approach is often integrative and interdisciplinary (Cabel \& Oelofse, 2012; Sporton, 2007).

\section{Methodology}

In this study, we focus on the resilience of semi-natural Mediterranean ecosystems in relation to multiple disturbances that can reduce the provision of ecosystem services, so-called "specified resilience" (Folke et al., 2010) or "resilience of what to what" (Carpenter et al., 2001). Each study site presents a different combination of LMPs and disturbances, as well as varying amounts/types of available scientific knowledge (e.g. literature or measurements) versus stakeholder knowledge. This means that we could not define specific indicators to assess the contribution of LMPs to the resilience of the ecosystem in advance. In order to have a systematic and reproducible methodology that could be implemented across different study sites, we chose to define a series of questions to be answered by a team of researchers, by consulting available scientific knowledge and discussing with stakeholders. Results concerning the role of LMPs were then translated into a semi-quantitative evaluation and combined in a single assessment using a mathematical index.

A synthetic assessment of the resilience of ecosystems is challenging because resilience is an emergent property, therefore it is influenced by multiple processes that are difficult to capture in a single evaluation (Domptail et al., 2013; Gunderson, 2000). Furthermore, different perceptions are involved in land management assessments, adding to the complexity of understanding resilience. Complex evaluations are however difficult to communicate and use, and reliance on simplified indices is a widely acknowledged technique in applied research projects (Costantini et al., 2016; Helldén \& Tottrup, 2008; Mcdonagh et al., 2009; Mumby et al., 2014; Pyke et al., 2013). Throughout our study we navigate between opposite needs: to generalize in order to obtain a usable methodology and results that would be relevant beyond the specific case, and to contextualize to have a meaningful assessment. Generalization is obtained by framing common questions and pre-defined answers that can be answered through both scientific and stakeholder knowledge, by cross-site comparison of results, and by grouping the LMPs by type. Contextualization is obtained by considering the land management system, including stakeholder perception and knowledge, and focusing on specific ecosystem services. 
In a preliminary phase of the research, we described a list of promising and common LMPs in the different study sites using the WOCAT technology questionnaire (WOCAT, 2008), and identified the respective land management systems, i.e. the land managed through a specific set of LMPs, by the same group of actors for a specific purpose. This allowed us to unambiguously identify the area of interest, the set of management practices, and the actors involved in the management that constituted the pool of stakeholders that were invited to participate in the assessment. Moreover, we proceeded to design the questionnaire using an iterative and participatory process (figure 1 and Method S1). The questionnaire (named Resilience Assessment Tool, or RAT, see Appendix S2) includes a characterization of the state of the system (e.g. state of most important ecosystem services and ecological features) according to land users' perceptions, types of disturbance and their impact on ecosystem services, role of land management in modulating the negative impact of disturbances, and external factors that could influence the dynamic of the land management system (e.g. policies, socioeconomic context, climatic trends). Answers are provided by choosing an option on a pre-defined list and adding details and comments in free text.

The first step of the implementation phase centred on engaging a comprehensive pool of stakeholders in participating in the assessment. To do so, we proceeded in a cascade way from the stakeholders that were already in contact with the researchers, from the preliminary phase of the research, to all the land users, land managers, and local administrators directly involved in the land management.

To increase reproducibility and comparability of results across site, we restricted the pool of stakeholders to those with a tangible influence on the land management of each study site, and aimed at consulting at least 10 stakeholders belonging to at least three different categories (land managers, land users, local administrators, experts/consultants). As many of the study sites are located in areas subject to land abandonment and outmigration, we had to reduce the number of people consulted; in one study site (Por_2, Traditional logging), the stakeholder group was limited to four. With such a low number of stakeholders the results may not be representative for the greater area, but they accurately reflect the views of those most directly involved with the land. Overall, 57 stakeholders (between three and 12 stakeholders per site) agreed to participate in workshops together with one or two researchers per study site. Information resulting from the first workshop was complemented and crosschecked with data obtained from local monitoring programmes, scientific literature, and direct observation by participating scientists. Inconsistencies and knowledge gaps were addressed by again consulting the stakeholders and local experts. Results were subsequently reviewed by an external group of researchers to ensure that complete and systematic answers were provided to each question. A complete list of sources used is presented in table S3.

After completing and reviewing all the questionnaires, we ranked the answers to questions of the RAT closely related to the contribution of LMPs to the resilience of the land management systems we studied. These questions related to: (1) the impact of disturbances on ecosystem services that were identified as important $(D)$ by stakeholders during group discussions (see Appendix S2, section 2); (2) the influence $(I)$ of land management in preventing a disturbance $(p)$, mitigating its negative effect $(m)$, or fostering recovery $(v)$ of the ecosystem's ability to supply important services (see Appendix S2, section 4); and (3) the resistance of an LMP to a disturbance (r), i.e. the extent to which the effectiveness of an LMP changes after the occurrence of a disturbance (see Appendix S2, section 4.3). Questions in the RAT were multiple-choice, with space in text boxes to justify the choice and provide further details for interpretation. These three evaluations $(D, I$, and $r$ ) were merged into a single resilience index $(R)$ to assess the contribution of each LMP to the resilience of the land management system to a specific disturbance. Examples for each variable considered in the assessment are 
presented in table 1 , while a detailed explanation of how the resilience index was calculated is presented in the following paragraphs.

\section{Insert table 1}

\subsection{Impact of disturbances}

To assess the impact of disturbances on ecosystem services, we first identified which ecosystem services are considered important by land managers. We relied upon the perception of stakeholders participating in the assessment, using the list of ecosystem services adapted from the WOCAT Technology questionnaire (WOCAT, 2008) and widely used for this kind of participatory assessment. The information was collected during group discussions using section 2 of the Resilience Assessment Tool (See Appendix S2, page 9, question 2.1 and 2.1.1). The ecosystem services are classified as "productive", "ecological", and "socio-cultural" and roughly correspond to the "provisioning", "regulating", and "cultural" categories used in the Millennium Ecosystem Assessment. Then, using both scientific and lay knowledge, we identified the ecosystem services that were likely to be degraded by each disturbance (See Appendix S2, section 4.1.3). The Impact $D$ of the disturbance $j$ was quantified through equation 1 :

$$
\left.D_{j}=E S_{j} / E S \quad \text { (Eq. } 1\right)
$$

where $E S$ is the number of ecosystems services identified as important by stakeholders, and $E S_{j}$ is the number of ecosystem services affected by the $j^{\text {th }}$ disturbance (among those services considered important). Equation 1 gives a number between 0 (no impact on important services) to 1 (all important services are affected).

\subsection{Influence and resistance of Land Management Practices}

By combining the information provided by the stakeholders with the scientific data available, we evaluated the influence of each LMP in (a) preventing a disturbance; (b) mitigating the negative impacts of a disturbance on the land management system; or (c) fostering recovery. This evaluation was conducted through answers to the following questions: "Does the LMP reduce the occurrence of disturbances?"; "Does the LMP mitigate the negative effect of disturbances?"; "Does the LMP help recover/restore the system after a disturbance? (See Appendix S2, section 4.2)". For the quantitative evaluation, we considered prevention, mitigation, and recovery as equal. This differs from the usual approach to land degradation, which considers prevention to be more important. We chose not to consider prevention as more important because some disturbances cannot be prevented through land management (e.g. droughts, floods). Moreover, ecological studies suggest that preventing the occurrence of a disturbance may in the long run make the ecosystem less resilient. (Carpenter et al., 2001; Merriam et al., 2006; Oliveira \& Fernandes, 2009)

The answers were transformed into values, derived from the pre-ranked list of five possibilities, ranging between -2 (degradation has heavily increased or recovery is prevented) and 2 (degradation is minimal or recovery is ensured). We combined the values related to prevention, mitigation, and recovery to obtain a single number indicating the direct influence of land management on the resilience of the system. Considering that prevention, mitigation, and restoration strategies are equally weighted, the influence ( $I$ ) of an LMP $i$ on the disturbance $j$ is calculated as per equation 2:

$$
I_{i, j}=p_{i, j}+m_{i, j}+v_{i, j}
$$


where $I_{i, j}$ is the influence of the $\mathrm{i}^{\text {th }}$ LMP on the $\mathrm{j}^{\text {th }}$ disturbance identified for the land management system, and $p_{i, j}, m_{i, j}$, and $v_{i, j}$ are, respectively, the influence of the $\mathrm{i}^{\text {th }} \mathrm{LMP}$ in preventing, mitigating, or assisting recovery from the $\mathrm{j}^{\text {th }}$ disturbance. As $p_{i, j}, m_{i, j}$ and $v_{i, j}$ have values between -2 and 2 , equation 2 results in a numerical value between -6 to 6 , where negative values correspond to net negative effects of land management in relation to a disturbance (increase in occurrence or in the related degradation), 0 corresponds to a negligible effect or a balanced combination of positive and negative effects, and positive values indicate a beneficial net effect of the practice. In this paper, we will use the term "positive" to refer to practices that increase resilience to a disturbance through prevention, mitigation, or recovery and the term "negative" to refer to practices decreasing the resilience of the ecosystem to a disturbance.

We also investigated resistance of LMPs to disturbances, i.e. any change in their effectiveness following the disturbance, using both scientific knowledge and stakeholder perception Assessing the resistance of LMPs to disturbances $\left(r_{i, j}\right)$, allows us to understand how the effectiveness of LMPs can change as a consequence of the disturbance itself. Identifying such feedbacks is extremely important to understanding resilience (Carpenter et al., 2009; Folke et al., 2004; Mitchell et al., 2014)., particularly for semi-natural ecosystems that are often of low economic value: in such cases, investments in land management are limited, especially in maintaining a practice. The resistance $r_{i, j}$ of a practice $i$ to a disturbance $j$ was assessed as a penalty to the influence $I$ on a point scale of 0 (the practice is as effective after as before the disturbance) to 3 (the effectiveness of the practice is negatively affected by the disturbance, leading to increased degradation). We adapted equation 3 so that a small beneficial influence of the LMP on the resilience of the ecosystems could be offset by a low resistance of the LMP to the disturbance. This choice was based on the fact that, in most cases, one or two disturbances have occurred since the implementation of the LMP. This might not be appropriate for studies involving much longer timespans or disturbances with a more frequent occurrence.

To enable cross-site comparison of the influence and resistance of similar LMPs, in the following text we have aggregated the values of $I$ and $r$ by type. In all cases, the arithmetic mean values are used.

\subsection{Overall resilience assessment}

Finally, we combined the impact of disturbances $D_{j}$, the influence of LMPs $I_{i, j}$, and the resistance of practices $r_{i, j}$ in an index using Equation 3 to calculate $R_{i, j}$ : the contribution of each LMP $i$ to the resilience of the land management system against the disturbance $j$. Considering that $I_{i, j}$ cannot be below the maximum negative effect of the influence of land management, $R_{i, j}$ is calculated as:

$$
R_{i, j}=D_{j}\left(I_{i, j}-r_{i, j}\right) / k
$$

where the value of $k$ is 6 , when $-6 \leq\left(I_{i, j}-r_{i, j}\right) \leq 6$, or 9 when $\left(I_{i, j}-r_{i, j}\right)<-6$. Eq. 3 results in a value between -1 and 1 , where all negative values indicate that the practice has a detrimental effect on resilience, 0 indicates a null or balanced effect, and positive values indicate a positive contribution of the LMP to resilience of ecosystems.

In order to evaluate the combination of LMPs used in the study site, we aggregated the values of $R$ by land management system using the arithmetic mean. 


\subsection{Study sites}

Our study focuses on eight sites in five countries in southern Europe (figure 2), where regime shifts have occurred or are likely to occur in the near future, due to anthropogenic or climate pressure. They are semi-natural ecosystems, dominated by Mediterranean forests and shrublands, but with a long history of land use that includes cropping. They are characterized by a variety of climatic conditions, from humid (Por_1 and Por_2) and sub-humid (Spa_2, Spa_3, Ita_1, Gre_1), to semi-arid (Spa_1, Cyp_2). All study sites except Spa_1 (Restored shrubland) and Spa_3 (Diversified shrubland) are still used for production: animal farming in the shrub-dominated areas (Ita_1, Gre_1, and Cyp_1), and wood production in the others (Por_1 and Por_2, and Spa_2 to lesser degree). All the study sites are affected by disturbances that have generated or are likely to generate long-term changes in the ecosystem, decreasing the supply of ecosystem services. All LMPs identified, with the exception of those in Por_1 and Por_2, had been implemented for a minimum of 10 years before this study began.

\section{Insert figure 2}

Another difference among the study sites is related to the respective main objectives of land management (table 2). These range from maximizing productivity (Por_2 Traditional logging) to reducing the impact of land use (Por_1 Conservation logging, Cyp_1 Extensive grazing) or restoring the ecological or productive value of the land (Spa_1 Restored shrubland, Spa_2 Restored forest, Gre_1 Silvopastoral system). Among their management objectives, three of the land management systems specifically include resilience or dealing with disturbances: Spa_3 Diversified shrubland, Ita_1 Seasonal pasture and, at least in part, Spa_2 Restored forest.

\section{Insert table 2}

4. Results

Throughout the eight study sites we identified a total of 16 LMPs (table 3) that were implemented prior to our study, either in combination (five study sites) or alone (three study sites). To extrapolate general indications and compare the contribution of LMPs to resilience across the sites, we grouped them according to the type of practical actions involved in each practice (table 3). Detailed description of LMPs is presented in table S4. In brief, Clearing of vegetation is aimed at reducing the biomass in fire prone areas. When implemented in forests, the wood extracted can be used for production. Grazing management focuses on regulating the access of animals that graze in a certain area throughout the year (Ita_1) or in particularly vulnerable periods (Gre_1). Planting of shrubs is a restoration practice for degraded areas, aimed at increasing vegetation cover and thereby reducing soil erosion, increasing fertility, and triggering the natural evolution of the ecosystem. Planting of trees is used both in forest areas (Spa_2) and in rangelands (Gre_1, Cyp_1) as a restoration measure. Finally, under Other, we classified two practices used in Cyprus, Carob tree protection from rats and Fodder provision to animals during summer, to mitigate degradation caused by grazing and pests.

\section{Insert table 3}

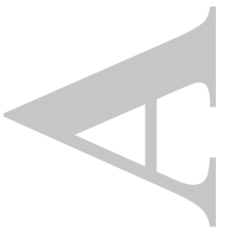




\subsection{Disturbances and impact on the supply of ecosystem services}

The first step in evaluating the impact of disturbances to ensure compatibility with the perception of stakeholders, focused on identifying the most important ecosystem services for them (table 4).

Insert table 4

In half of the study sites, both "productive" and "ecological" services were indicated as valuable, while in only two of them no productive services were deemed valuable. Among the ecological services, "reduced erosion" is the most frequently indicated (six out of eight study sites), followed by "above-ground biodiversity" (four out of eight) and "protection from extreme events". Sociocultural services are the ones least considered, with no study site indicating both recreational and cultural services.

Having identified the most important ecosystem services, we evaluated how each disturbance could affect them using eq. 1 (table 5).

Insert table 5

In seven out of eight study sites, more than one disturbance was reported as likely to decrease the provision of important ecosystem services. The disturbances most commonly reported were also those with the greatest impact: droughts and wildfires. Wildfire affects not only the forest systems but also the pastoral ones. Exceptions include Restored shrubland (Spa_1) and Seasonal pasture (Ita_1). The second most commonly reported disturbance is drought, affecting five of the eight land management systems. Third are outbreaks of pests and diseases, including plant diseases (e.g. nematodes and Tomicus beetles in forests), animal diseases (in grazing systems), but also animal pests: Ita_1 pastures are affected by wild boars that disrupt the grass layer; Cyp_1 shrublands are affected by brown rats, which attack the carob trees, increasing their mortality. Torrential rainfalls refers to heavy rains that create significant concentrated erosion rills, and can trigger the creation of gullies. Floods refers to a temporaryinundation of the area due to overflow from neighbouring streams.

\subsection{Influence of LMPs on disturbances}

The second step in assessing the contribution of LMPs to the resilience of forest and rangeland consists of evaluating how LMPs influence the system when a disturbance occurs $I_{i, j}$, and how they are affected by the disturbance $r_{i, j}$. Values of $I_{i, j}$ above 0 identify LMPs as "positive" (increasing resilience to a disturbance), while Values of $I_{i, j}$ below 0 indicate a "negative" influence (decreasing resilience). $r_{i, j}$ values below 1 identify an LMP as "non-resistant". The results of both evaluations are presented in figure 3.

Insert figure 3

Most LMPs assessed have a positive influence on the disturbances studied (i.e. they reduce the land degradation caused by the disturbance), with the exception of Grazing management, which was the only LMP assessed to have a negative influence on resilience (drought). All the practices appear to have very different levels of influence and resistance depending on the disturbance considered. In particular, Grazing management practices were considered positive and resistant only in relation to pests and diseases, negative but resistant in relation to droughts, and positive but not resistant in relation to fires. Clearing of vegetation was judged to be positive not only against wildfires and pests and diseases but also in relation to droughts. In grazing systems Planting of trees was judged positive 
and resistant in relation to floods, but not resistant in relation to droughts and scarcely resistant to fires. Similarly, shrub planting was assessed to have a positive effect on the ecosystem's resilience to fire, and to a lesser degree, torrential rainfall, but negative effects on resilience to drought and flood.

4.3. Overall contribution of land management practices (LMPs) to resilience of ecosystems

Having assessed the impact of disturbances on the land management system and the influence of LMPs when a disturbance occurs, we can now evaluate the overall contribution of LMPs to the resilience of the land management system using eq. 3 (table 6 and figure 4.)

\section{Insert table 6}

Most practices were assessed as having a positive impact on the resilience of the land management systems in which they were implemented, in relation to at least one disturbance. The removal of vegetation (Selective clearing in Spa_2, shrub clearing in Spa_3) was assessed to be very positive for resilience (average R value: 0.45). Moreover, Traditional logging in Por_2 (average R value: 0.17) was assessed as more resilient than Conservation logging in Por_1 (average $R$ value: -0.125), the former involving more vegetation removal than the latter. Planting of vegetation was assessed as mostly detrimental to resilience: Afforestation with P. halepensis in Spa_2 appears to have a negative role in relation to fires ( $\mathrm{R}$ value: -0.33), as does the resprouter shrub plantation in Spa_1 against droughts (R value: -0.33). In rangeland systems, the Fences adopted in the Italian study site appear to be very effective against pests. Carob afforestation scores a higher value against fire in the silvopastoral system (Gre_l) compared to extensive grazing (Cyp_l).

\section{Insert figure 4}

When considering the combined contribution of LMPs to the resilience of their land management system, seasonal pasture (Ita_1, R value: 0.33), diversified shrubland (Spa_3, average R value: 0.19), and restored forest (Spa_2, average $\mathrm{R}$ value: 0.11 ) were assessed as the most positive case studies. Only Conservation logging (Por_1, average $\mathrm{R}$ value: 0.13 ) was assessed to decrease the overall resilience of the system. However, in six out of eight study sites, LMPs had some negative impacts on resilience. In particular, restored forest in Spain (Spa_2), where selective cutting and planting of fire resilient species was applied, scored the lowest and the highest values (-0.33 and 0.67 respectively, table 6) of the whole assessment. Among the forest systems, it appears that the LMPs of the restored forest (Spa_2) contribute most to the resilience of the system.

5. Discussion

\subsection{Methodological approach to resilience assessment}

Our methodology was based on an integrative approach (Mauser et al., 2013) directed at combining, rather than dissecting, knowledge and information. This applies mainly to the study of the role of LMPs: we assessed the outcome of a certain practice implemented in a certain context in relation to a certain disturbance, without analysing separately each variable that leads to such outcome. This may have led to a difference in the assessment across different study sites, since there is some indication that the effects of practices may depend on the conditions of the system itself before the disturbance (Walker et al., 2010) and other contextual factors such as the landscape (Jucker Riva et al., 2017) and time of implementation (Jucker Riva et al., 2016). An example was the different evaluation of Carob plantation with regards to fire in Cyprus and Greece. The contextual information about the land management systems collected through the Resilience Assessment Tool enabled us to explain 
differences not captured through the numerical evaluation. We also tried to capture stakeholder perception in an integrative way, i.e. by encouraging different actors to share and confront their views with others during group discussions. This approach allowed us to obtain a unified picture of stakeholders' perceptions, but did not expose underlying power relations or agendas that might have influenced the participatory process.

The first step of our analysis focused on identifying which ecosystem services are to be maintained or restored. This approach allowed us to clearly evaluate the impact of disturbances across different study sites, but it does not integrate all the possible ways a system can cope with disturbances (Briske et al., 2010; Gunderson, 2000; Mumby et al., 2014). Rather than focusing on resisting, recovering, or adapting the land management, in certain cases it may be worthwhile transforming (O'Connell et al., 2016; Walker et al., 2004), (i.e. changing) the land use entirely in order to make use of a different set of ecosystem services, which may arise after a disturbance or may turn out to be more stable. A separate study should be carried out to evaluate the possibilities, advantages, and disadvantages of transforming the land use system to one that is less affected by disturbances, involving different stakeholders, processes, and scales.

5.2. Assessing the Influence $\left(I_{i, j}\right)$, Resistance $\left(r_{i, j}\right)$ and overall contribution of LMPs to Resilience of ecosystems $\left(R_{i, j}\right)$

From our assessment of the resistance of LMPs, revegetation practices such as shrub and tree planting are more at risk of collapsing after a disturbance: Afforestation with pines and shrub planting were assessed to be particularly vulnerable to both droughts and fires. The value of these practices is highly debated among scientists (Maestre \& Cortina, 2004a; Pausas et al., 2004; Vallejo et al., 2012), especially if they are not combined with other practices that focus on increasing resilience (Seidl et al., 2016).

In order to compare and combine results across study sites, we chose to calculate the contribution of each LMP to resilience ( $R$ value, see equation 3 ) separately, even if the practices are usually implemented in combination (e.g. Tree planting and Clearing of vegetation in Spain vs. Tree planting and Controlled grazing in Greece). With the exception Restored shrubland (Spa_1), the practices implemented over the same study site are of very different types, making it possible to distinguish the effects of one from the other. For example, in the case of Restored forest (Spa_2), management consists of three LMPs of two different types: Planting of trees (pine afforestation) and Clearing of vegetation (fuel breaks and selective clearing, see table 3). Planting of trees and Clearing of vegetation entail opposing interactions with the environment, and thus it was easy to identify the influence of afforestation on resilience. Fuel breaks are implemented at specific sites only, while selective clearing is implemented over wide areas, so it was possible for both land managers and scientists to distinguish the role of one practice from the other by comparing different sites within the forest stand.

Our results show how double-edged the contribution of LMPs to resilience can be, depending on the disturbance type and the context. Carob plantation was assessed as increasing the resilience against fire in Greece ( $\mathrm{R}$ value: 0.13 ) but decreasing it in Cyprus ( $\mathrm{R}$ value: -0.08 ) due to a difference in context: in Cyprus, the average biomass density of the shrublands is much lower, and so planting carob could increase the amount and continuity of fuel present; in Greece, the fuel amount and connectivity of vegetation are higher, and so the presence of carob does not further increase the risk of fire. Thus, Carob plantation increases resilience to drought (Gre_1, Cyp_1) but can reduce resilience to fire (Cyp_1). 
The wide range of scores obtained by LMPs in relation to drought and fire (e.g. Spa $\_2,0.75$, see table 6) suggests that increasing resilience to both disturbances at the same time could be difficult, as practices aimed at dealing with fire reduce resilience against drought. This is very relevant because the two disturbances are often linked, and one tends to reinforce the other (Bigler et al., 2005). Scientists have previously stressed the importance of considering multiple disturbances at once (Buma \& Wessman, 2011; Turner, 2010), but it is difficult to find studies that propose practical solutions. Selective clearing increases resilience to fire and drought, respectively, by reducing the flammable biomass and by increasing the water available per individual plant (Spa_2, Spa_3). In grazing areas, Fodder provision appears to have positive impacts on resilience, regardless of the disturbance affecting the system. In general, no single practice was able to increase resilience to all disturbances while maintaining its effectiveness. The highly variable scores obtained by all the practices in relation to different disturbances suggest that multiple practices are needed to tackle the full spectrum of disturbances that may harm an ecosystem.

The results of our assessment are consistent with a separate study (Valdecantos et al., 2016) based on the Landscape Function Analysis procedure of Tongway \& Hindley (2004). The other study was carried out in the same sites comparing an undisturbed area, a degraded area, and an area that had been managed or restored. Consistent with our results, the study by Valdecantos et al. found that Traditional logging in Portugal appeared to improve ecosystem services supply more than Conservation logging, Tree planting in Cyprus and Greece improved water infiltration and nutrient cycling and reduced erosion, Selective Clearing and planting in shrubland in Spain improved biodiversity and permanently reduced fuel load. The systems that scored the highest values from our assessment are indeed those that explicitly include dealing with disturbances among their management objectives: Seasonal pasture in Italy; Diversified shrubland and Restored forest in Spain. In our interpretation, the high scores of the land management systems Ita_1, Spa_3, and Spa_2 are related to the fact that the practices implemented aim at reducing the impact of the most relevant disturbances; in other words, resilience is among the objectives of the land management strategy.

\subsection{Resilience values by type of practice and land management system}

After the assessment we classified the practices by type, and proceeded to combine the results of the assessment by type of practice and by land management system. This step was essential to draw conclusions about the overall contribution of land management to the resilience of each study site, and enable a cross-site comparison of practices (e.g. tree planting in Spain and Cyprus).

When considering the combination of LMPs implemented in each study site in relation to multiple disturbances, management strategies addressed at improving the environment did not necessarily prove valuable for increasing resilience. Restoration practices belonging to the planting of trees type were considered not resistant to droughts and fires. This casts doubt over the long-term effectiveness of this type of practice when implemented in drylands that are frequently affected by those disturbances (Maestre \& Cortina, 2004b; Pausas et al., 2004). The detrimental influence of Conservation logging is particularly interesting: the dead woody material left on the ground reduces soil erosion by rain, but it also increases the chances of both fire and disease outbreaks, decreasing the resilience of the system (Prats et al., 2012). The negative influence on resilience scored by Grazing management was unexpected, as moderate grazing has been reported to favour ecological functioning and the overall provision of services in Mediterranean rangelands (Papanastasis et al., 2015), and to reduce fuel load and competition between plants. However, while a given grazing intensity could be adequate for periods under normal climatic conditions, the combined pressure of grazing and drought may increase plant mortality above a critical threshold and trigger ecosystem collapse (He et al., 
2017). Furthermore, grazing- and drought-induced mortality may be higher for palatable grasses and wide-leafed shrubs than for unpalatable species, leading to a decrease in fodder value even after a resting period during which a pasture is not used for grazing (Caldeira et al., 2015). Only Clearing of vegetation scored high values against multiple disturbances. Indeed, a selective and partial clearing of vegetation reduces fuel load (relevant for resilience against fire), favours the growth of the remaining plants, and reduces the competition for water among individuals - all of them factors that favour recovery of ecosystems in a wide variety of situations (Baeza \& Vallejo, 2008).

\subsection{Relation between resilience and sustainability}

Resilience of ecosystems is considered by some scientists to be part of sustainability (Hurni, 2000). In practice, however, we have detected a conflict between reducing land degradation and managing for resilience: Conservation logging applied in Portugal to reduce the impacts of logging on soil was revealed to be far less beneficial to resilience than Traditional logging (figure 4). This, together with the shortcomings identified for tree and Shrub planting, highlights the risks and uncertainties associated with strong interventions aimed at controlling or modifying specific aspects of the ecosystem (Domptail et al., 2013; Hilderbrand et al., 2005). In accordance with recent research, it appears that allowing for self-organization (Bergamini et al., 2013; Choptiany et al., 2016; Peterson, 2000), e.g. through selective vegetation removal, is far more beneficial. Diversity, often associated with increased resilience in scientific literature (Acácio \& Holmgren, 2014; Bennett et al., 2015; Elmqvist et al., 2003; Lavorel, 1999) appears to be relevant for our study: the enhanced species diversity after Shrub planting in Spa_1 and Spa_3 increased the resilience of land management systems in Spa_1 and Spa_3; since few LMPs proved beneficial against multiple disturbances, an increase in resilience could be achieved by diversifying the management. Finally, our results appear to support the "resilience thinking" approach (Folke et al., 2010; Mitchell et al., 2014; Rist \& Moen, 2013; Walker \& Salt, 2012): land management systems that included increasing resilience or coping with disturbances among their management objectives proved to be more successful in increasing resilience of ecosystems.

\section{Conclusion}

Our study focuses on the role of land management practices (LMPs) in relation to the disturbances that affect several Mediterranean ecosystems, using information collected through a knowledge cocreation approach evaluated through a synthetic, semi-quantitative index. By evaluating the land management options in detail, we are able to highlight important practical information for land managers to increase the resilience of their ecosystems. Our spatially explicit definition of land management systems allowed us to study both the natural environment and human actions, and is flexible enough to be adapted to a wide variety of areas. Involving stakeholders allowed us to not only include different perspectives, but also to overcome knowledge gaps and missing information that would have required long-term monitoring and field observations.

The results of our assessment revealed that the practices analysed are particularly effective against wildfires and torrential rainfalls. By contrast, droughts are more difficult to counter and all LMPs were heavily affected by their occurrence. The effectiveness of LMPs belonging to the Tree planting group appears highly sensitive to disturbances, calling into question their value in areas that are frequently affected by disturbances. By contrast, LMPs that selectively reduce the amount of vegetation appear to be beneficial in fostering recovery of ecosystems. Furthermore, our assessment suggests that there are potential incompatibilities among land management objectives: increasing 
resilience of ecosystems to drought appears to reduce resilience to fire, and reducing the impact of logging in forests appears to reduce resilience to fire and pest outbreaks.

From our study, we have derived several practical indications of how to increase the resilience of Mediterranean ecosystems threatened by disturbances, relevant for land management planning and policymaking. First, promote the use of multiple (rather than few) ecosystem services, as this makes disturbances less impacting for land users. Second, implement multiple land management practices, focused on preventing, mitigating, or fostering recovery in relation to different disturbances, because single LMPs fail to provide benefits in relation to different disturbances, especially if both drought and fire are likely to occur. Third, consider the resistance of LMPs and act to restore their effectiveness if needed, as LMPs may cease to provide benefits and even cause harm to the ecosystem after a disturbance has occurred. Fourth, carefully consider the long term value of heavy restoration interventions such as pine afforestation, since they are heavily impacted by disturbances.

The methodology used in this study allowed us to synthetically evaluate the combined effect of different LMPs in relation to several disturbances. Furthermore, the methodology could be integrated into sustainability assessments and land management planning tools to facilitate "resilience thinking". To enhance the robustness of results and their applicability across different ecosystems, future studies should include specific indicators for ecological processes that influence resilience to different disturbances.

\section{Acknowledgements}

For their contribution and help in gathering information, we thank Costas Michael from the Department of Agriculture and Adamos Markides from the Department of Forest (Cyprus); Miquel G. Bartual, Alberto Vilagrosa, Esteban Chirino, and Daniel Ferrández (Spain); Sandra Valente, Celeste Coelho, Oscar González-Pelayo, Victor Santana and Paula Maia, Eng. Rui Melo (Director) and Eng. Rui Pedro Ferreira of the Institute for the Conservation of Nature and Forests (Portugal); Ioanna Panagea, Dr. Marinos Kritsotakis, Kostas Karatzis (Greece); Velia de Paola (University of Basilicata, Italy). We thank Tina Hirschbuehl and Anu Lannen for the language editing and the anonymous reviewers for their detailed comments.

This paper was developed within the CASCADE project (Seventh Framework Programme FP7/20072013 grant agreement 283068). For their financial support we thank CESAM (UID/AMB/50017), FTC/MEC, FEDER and PT2020 Partnership Agreement (Portugal); Generalitat Valenciana (DESESTRES - program PROMETEO II/2014/038, Spain), Compete 2020 and ESSEM COST Action ES1104.

8. Supporting information:

Method S1. Design process of the Resilience Assessment Tool and interactions with different stakeholder groups

Appendix S2. Resilience assessment Tool

Table S3. Sources used to assess the contribution of land management to resilience of Mediterranean forests and rangelands

Table S4. Detailed description of land management practices assessed 


\section{References}

Acácio V, Holmgren M. 2014. Pathways for resilience in Mediterranean cork oak land use systems. Annals of Forest Science. Springer Paris, 5-13. DOI: 10.1007/s13595-012-0197-0

Alados CL, Puigdefábregas J, Martínez-Fernández J. 2011. Ecological and socio-economical thresholds of land and plant-community degradation in semi-arid Mediterranean areas of southeastern Spain. Journal of Arid Environments 75: 1368-1376. DOI: 10.1016/j.jaridenv.2010.12.004

Baeza MJ, Valdecantos A, Alloza JA, Vallejo R V. 2007. Human disturbance and environmental factors as drivers of long-term post-fire regeneration patterns in Mediterranean forests. Journal of Vegetation Science 18: 243. DOI: 10.1658/1100-9233(2007)18[243:HDAEFA]2.0.CO;2

Baeza MJ, Vallejo R V. 2008. Vegetation recovery after fuel management in Mediterranean shrublands. Applied Vegetation Science 11: 151-158. DOI: 10.3170/2007-7-18339

Bautista S, Llovet J, Ocampo-Melgar A, Vilagrosa A, Mayor AG, Murias C, Vallejo R V., Orr BJ. 2017. Integrating knowledge exchange and the assessment of dryland management alternatives A learning-centered participatory approach. Journal of Environmental Management 195: 35-45. DOI: $10.1016 /$ j.jenvman.2016.11.050

Bennett EM, Cramer W, Begossi A, Cundill G, Díaz S, Egoh BN, Geijzendorffer IR, Krug CB, Lavorel S, Lazos E, Lebel L, Martín-López B, Meyfroidt P, Mooney H a, Nel JL, Pascual U, Payet K, Harguindeguy NP, Peterson GD, Prieur-Richard A-H, Reyers B, Roebeling P, Seppelt R, Solan M, Tschakert P, Tscharntke T, Turner B, Verburg PH, Viglizzo EF, White PC, Woodward G. 2015. Linking biodiversity, ecosystem services, and human well-being: three challenges for designing research for sustainability. Current Opinion in Environmental Sustainability 14: 76-85. DOI: 10.1016/j.cosust.2015.03.007

Bérard A, Bouchet T, Sévenier G, Pablo AL, Gros R. 2011. Resilience of soil microbial communities impacted by severe drought and high temperature in the context of Mediterranean heat waves. European Journal of Soil Biology 47: 333-342. DOI: 10.1016/j.ejsobi.2011.08.004

Bergamini N, Blasiak R, Eyzaguirre P, Ichikawa K, Mijatovic D, Fumiko N, Subramanian SM. 2013. Indicators of Resilience in Socio-ecological Production Landscapes ( SEPLs ).

Bernués A, Ruiz R, Olaizola A, Villalba D, Casasús I. 2011. Sustainability of pasture-based livestock farming systems in the European Mediterranean context: Synergies and trade-offs. Livestock Science 139: 44-57. DOI: 10.1016/j.livsci.2011.03.018

Bigler C, Kulakowski D, Veblen TT. 2005. Multiple disturbance interactions and drought influence fire severity in rocky mountain subalpine forests. Ecology 86: 3018-3029. DOI: 10.1890/050011

Blondel J. 2006. The "design" of Mediterranean landscapes: A millennial story of humans and ecological systems during the historic period. Human Ecology 34: 713-729. DOI: $10.1007 / \mathrm{s} 10745-006-9030-4$

Bowman DMJS, Williamson GJ, Prior LD, Murphy BP. 2016. The relative importance of intrinsic and extrinsic factors in the decline of obligate seeder forests. Global Ecology and Biogeography 25: 1166-1172. DOI: $10.1111 /$ geb. 12484

Briske DD, Washington-allen RA, Johnson CR, Lockwood JA. 2010. Catastrophic Thresholds : A Synthesis of Concepts, Perspectives, and Applications. Ecology and Society 15: 37

Buma B, Wessman C a. 2011. Disturbance interactions can impact resilience mechanisms of forests. 
Ecosphere 2: art64. DOI: 10.1890/ES11-00038.1

Bunning S, Mcdonagh J, Rioux J. 2011. LADA-Land Degradation Assessment in Drylands. Rome

Cabel JF, Oelofse M. 2012. An indicator framework for assessing agroecosystem resilience. Ecology and Society 17. DOI: $10.5751 / \mathrm{ES}-04666-170118$

Caldeira MC, Lecomte X, David TS, Pinto JG, Bugalho MN, Werner C. 2015. Synergy of extreme drought and shrub invasion reduce ecosystem functioning and resilience in water-limited climates. Scientific Reports 5: 15110. DOI: 10.1038/srep15110

Carpenter S, Walker B, Anderies JM, Abel N. 2001. From Metaphor to Measurement: Resilience of What to What? Ecosystems 4: 765-781. DOI: 10.1007/s10021-001-0045-9

Carpenter SR, Mooney HA, Agard J, Capistrano D, DeFries RS, Diaz S, Dietz T, Duraiappah AK, Oteng-Yeboah A, Pereira HM, Perrings C, Reid W V., Sarukhan J, Scholes RJ, Whyte A, Díaz S, Dietz T, Duraiappah AK, Oteng-Yeboah A, Pereira HM, Perrings C, Reid W V., Sarukhan J, Scholes RJ, Whyte A. 2009. Science for managing ecosystem services: Beyond the Millennium Ecosystem Assessment. Proceedings of the National Academy of Sciences of the United States of America 106: 1305-12. DOI: 10.1073/pnas.0808772106

Choptiany J, Graub B, Philips S, Colozza D, Dixon J. 2016. Self-evaluation and Holistic Assessment of Climate Resilience of Farmers and Pastoralists.

Costantini EAC, Branquinho C, Nunes A, Schwilch G, Stavi I, Valdecantos A, Zucca C. 2016. Soil indicators to assess the effectiveness of restoration strategies in dryland ecosystems. Solid Earth 7: 397-414. DOI: 10.5194/se-7-397-2016

Crépin A-S, Biggs R, Polasky S, Troell M, de Zeeuw A. 2012. Regime shifts and management. Ecological Economics 84: 15-22. DOI: 10.1016/j.ecolecon.2012.09.003

Cumming GS, Barnes G, Perz S, Schmink M, Sieving KE, Southworth J, Binford M, Holt RD, Stickler C, Van Holt T. 2005. An exploratory framework for the empirical measurement of resilience. Ecosystems 8: 975-987. DOI: 10.1007/s10021-005-0129-z

Daliakopoulos IN, Panagea IS, Tsanis IK, Grillakis MG, Koutroulis AG, Hessel R, Mayor AG, Ritsema CJ. 2017. Yield Response of Mediterranean Rangelands under a Changing Climate. Land Degradation \& Development. DOI: 10.1002/ldr.2717

Davoudi S, Shaw K, Haider LJ, Quinlan AE, Peterson GD, Wilkinson C, Fünfgeld H, McEvoy D, Porter L, Davoudi S. 2012. Resilience: A Bridging Concept or a Dead End? "Reframing" Resilience: Challenges for Planning Theory and Practice Interacting Traps: Resilience Assessment of a Pasture Management System in Northern Afghanistan Urban Resilience: What Does it Mean in Planni. Planning Theory \& Practice 13: 299-333. DOI: 10.1080/14649357.2012.677124

Dixon J, Stringer L. 2015. Towards a Theoretical Grounding of Climate Resilience Assessments for Smallholder Farming Systems in Sub-Saharan Africa. Resources 4: 128-154. DOI: 10.3390/resources4010128

Domptail S, Easdale MH, Yuerlita. 2013. Managing Socio-Ecological Systems to Achieve Sustainability: A Study of Resilience and Robustness. Environmental Policy and Governance 23: 30-45. DOI: 10.1002/eet.1604

ELD Initiative. 2015. Pathways and options for action and stakeholder engagement, based on the 2015 ELD Massive Open Online Course "Stakeholder Engagement”. Practitioner's Guide.

Elmqvist T, Folke CS, Nystrom M, Peterson GD, Bengtsson J, Walker B, Norberg J, Nystrm M, 
Nyström M. 2003. Response diversity, ecosystem change, and resilience. Frontiers in Ecology and the Environment 1: 488-494. DOI: 10.1890/1540-9295(2003)001[0488:RDECAR]2.0.CO;2

FAO, UNEP. 1999. Guidelines for integrated planning for sustainable management of land resources. Rome

Folke CS, Carpenter SR, Walker B, Scheffer M, Chapin T, Rockstrom J. 2010. Resilience thinking: Integrating resilience, adaptability and transformability. Ecology and Society 15: 20. DOI: 10.1038/nnano.2011.191

Folke CS, Carpenter SSR, Walker B, Scheffer M, Elmqvist T, Gunderson LH, Holling CS. 2004. Regime shifts, resilience, and biodiversity in ecosystem management. Annual Review of Ecology and Evolution 35: 557-581. DOI: 10.1146/annurev.ecolsys.35.021103.105711

Groffman PM, Baron JS, Blett T, Gold AJ, Goodman I, Gunderson LH, Levinson BM, Palmer MA, Paerl HW, Peterson GD, Poff NL, Rejeski DW, Reynolds JF, Turner MG, Weathers KC, Wiens J. 2006. Ecological thresholds: The key to successful environmental management or an important concept with no practical application? Ecosystems 9: 1-13. DOI: 10.1007/s10021003-0142-z

Gunderson LH. 2000. Ecological Resilience in Theory and Application. Ecology and Systematics 31: 425-439. DOI: 10.1146/annurev.ecolsys.31.1.425

Hadorn GH, Bradley D, Pohl C, Rist S, Wiesmann U. 2006. Implications of transdisciplinarity for sustainable research. Ecological economics 60: 119-128. DOI: 10.1016/j.ecolecon.2005.12.002

He Q, Silliman BR, Liu Z, Cui B. 2017. Natural enemies govern ecosystem resilience in the face of extreme drought. Ecology Letters 20: 194-201. DOI: 10.1002/ldr.2368

Helldén U, Tottrup C. 2008. Regional desertification: A global synthesis. Global and Planetary Change 64: 169-176. DOI: 10.1016/j.gloplacha.2008.10.006

Hilderbrand RH, Watts AC, Randle AM. 2005. The Myths of Restoration Ecology. Ecology and Society 10

Holling CS. 1973. Resilience and Stability of Ecological Systems. Annual Review of Ecology and Systematics 4: 1-23. DOI: 10.1146/annurev.es.04.110173.000245

Hurni H. 2000. Assessing sustainable land management (SLM). Agriculture, Ecosystems \& Environment 81: 83-92. DOI: 10.1016/S0167-8809(00)00182-1

Jucker Riva M, Daliakopoulos IN, Eckert S, Hodel E, Liniger H. 2017. Assessment of Land Degradation in Mediterranean Forests and Grazing Lands using a Landscape Unit Approach and the Normalized Difference Vegetation Index. Applied Geography 86: 8-21. DOI: 10.1016/j.apgeog.2017.06.017

Jucker Riva M, Liniger H, Valdecantos A, Schwilch G. 2016. Impacts of land management on the resilience of Mediterranean dry forests to fire. Sustainability (Switzerland) 8: 981. DOI: 10.20944/preprints201607.0081.v1

Kizos T, Detsis V, Iosifides T, Metaxakis M. 2014. Social capital and social-ecological resilience in the Asteroussia Mountains, Southern Crete, Greece. Ecology and Society 19. DOI: 10.5751/ES06208-190140

Knox KJE, Clarke PJ. 2012. Fire severity, feedback effects and resilience to alternative community states in forest assemblages. Forest Ecology and Management 265: 47-54. DOI: 10.1016/j.foreco.2011.10.025 
Lavorel S. 1999. Ecological diversity and resilience of Mediterranean vegetation to disturbance. Diversity and Distributions 5: 3-13. DOI: 10.1046/j.1472-4642.1999.00033.x

Liniger H, Mekdaschi R, Providoli I. 2013. Promoting best practices in sustainable land management. Rural 21: the international journal for rural development 47: 14-15

Liniger H, Mekdaschi RS, Moll P, Zander U. 2017. Making sense of research for sustainable land management.

Liniger H, Schwilch G. 2002. Enhanced Decision-Making Based on Local Knowledge. Mountain Research and Development 22: 14-18. DOI: $10.1659 / 0276-$ 4741(2002)022[0014:EDMBOL]2.0.CO;2

Lozano FJ, Surez-Seoane S, De Luis-Calabuig E. 2012. Does fire regime affect both temporal patterns and drivers of vegetation recovery in a resilient Mediterranean landscape? A remote sensing approach at two observation levels. International Journal of Wildland Fire 21: 666-679. DOI: 10.1071/WF10072

Maestre FT, Cortina J. 2004a. Are Pinus halepensis plantations useful as a restoration tool in semiarid Mediterranean areas? Forest Ecology and Management 198: 303-317. DOI: 10.1016/j.foreco.2004.05.040

Maestre FT, Cortina J. 2004b. Are Pinus halepensis plantations useful as a restoration tool in semiarid Mediterranean areas? Forest Ecology and Management 198: 303-317. DOI: 10.1016/j.foreco.2004.05.040

Mauser W, Klepper G, Rice M, Schmalzbauer BS, Hackmann H, Leemans R, Moore H. 2013. Transdisciplinary global change research: The co-creation of knowledge for sustainability. Current Opinion in Environmental Sustainability 5: 420-431. DOI: 10.1016/j.cosust.2013.07.001

Mayor AG, Valdecantos A, Vallejo R V., Keizer JJ, Bloem J, Baeza MJ, González-Pelayo O, Machado AI, de Ruiter PC. 2016. Fire-induced pine woodland to shrubland transitions in Southern Europe may promote shifts in soil fertility. Science of The Total Environment. DOI: 10.1016/j.scitotenv.2016.03.243

Mcdonagh J, Bunning S, Douglas M. 2009. Field Guide for Rapid Local Land Resources Assessment in Drylands. Policy

Merriam KE, Keeley JE, Beyers JL. 2006. Fuel breaks affect nonnative species abundance in Californian plant communities. Ecological Applications 16: 515-527. DOI: 10.1890/10510761(2006)016[0515:FBANSA]2.0.CO;2

Mitchell M, Griffith R, Ryan P, Walkerden G, Walker B, Brown VA, Robinson S. 2014. Applying resilience thinking to natural resource management through a \&quot; planning-by-doing \&quot; framework. . DOI: 10.1080/08941920.2013.861556

Mumby PJ, Chollett I, Bozec Y-M, Wolff NH. 2014. Ecological resilience, robustness and vulnerability: how do these concepts benefit ecosystem management? Current Opinion in Environmental Sustainability 7: 22-27. DOI: http://dx.doi.org/10.1016/j.cosust.2013.11.021

O’Connell D, Abel N, Grigg N, Maru Y, Butler J, Cowie AL, Stone-Jovicich S, Walker B, Wise R, Ruhweza, A., Pearson, L., Ryan, P., Stafford Smith M, O'Connell D, Abel N, Grigg N, Maru Y, Butler J, Cowie AL, Stone-Jovicich S, Walker B, Wise R, Ruhweza, A., Pearson, L., Ryan, P., Stafford Smith M. 2016. DESIGNING PROJECTS IN A RAPIDLY CHANGING WORLD Guidelines for embedding resilience, adaptation and transformation into sustainable development projects. Washington, D.C. 
Oliveira S, Fernandes P. 2009. Regeneration of Pinus and Quercus after fire in Mediterranean-type ecosystems: natural mechanisms and management practices. Silva Lusitana 17: 181-192

Papanastasis VP, Bautista S, Chouvardas D, Mantzanas K, Papadimitriou M, Mayor AG, Koukioumi P, Papaioannou A, Vallejo R V. 2015. Comparative Assessment of Goods and Services Provided By Grazing Regulation and Reforestation in Degraded Mediterranean Rangelands. Land Degradation \& Development n/a-n/a. DOI: 10.1002/ldr.2368

Pausas JG, Bladé C, Valdecantos A, Seva JP, Fuentes D, Alloza JA, Vilagrosa A, Bautista S, Cortina J, Vallejo R V. 2004. Pines and oaks in the restoration of Mediterranean landscapes of Spain: New perspectives for an old practice - a review. Plant Ecology 171: 209-220

Pausas JG, Llovet J, Rodrigo A, Vallejo R V. 2008. Are wildfires a disaster in the Mediterranean basin? A review. International Journal of Wildland Fire 17: 713-723. DOI: 10.1071/WF07151

Peterson GD. 2000. Scaling ecological dynamics: Self-organization, hierarchical structure, and ecological resilience. Climatic Change, 291-309. DOI: 10.1023/A:1005502718799

Plummer R, Armitage D. 2007. A resilience-based framework for evaluating adaptive comanagement: Linking ecology, economics and society in a complex world. Ecological Economics 61: 62-74. DOI: 10.1016/j.ecolecon.2006.09.025

Pohl C, Hirsch Hadorn G. 2007. Principles for designing transdisciplinary research. Swiss Academies of Arts and Sciences, 36-40. DOI: ISBN 978-3-86581-046-5

Pohl C, Rist S, Zimmermann A, Fry P, Gurung GS, Schneider F, Speranza CI, Kiteme B, Boillat S, Serrano E. 2010. Researchers' roles in knowledge co-production: experience from sustainability research in Kenya, Switzerland, Bolivia and Nepal. Science and Public Policy 37: 267-281

Prats SA, MacDonald LH, Monteiro M, Ferreira AJD, Coelho COA, Keizer JJ. 2012. Effectiveness of forest residue mulching in reducing post-fire runoff and erosion in a pine and a eucalypt plantation in north-central Portugal. Geoderma 191: 115-124. DOI: 10.1016/j.geoderma.2012.02.009

Pyke DA, Herrick JE, Shaver P, Pellant M. 2013. Rangeland health attributes and indicators for qualitative assessment. Journal of Range Management 55: 584-597. DOI: 10.2307/4004002

Reed MS, Dougill AJ, Baker TR. 2008. Participatory indicator development: what can ecologists and local communities learn from each other? Ecological applications: a publication of the Ecological Society of America 18: 1253-69

Regeer BJ, Bunders JFG. 2009. Knowledge co-creation: Interaction between science and society A transdisciplinary approach to complex societal issues.

Resilience Alliance. 2010. Assessing resilience in Social-Ecological Systems - A workbook for practitioners $v$ 2.0. Transformation. DOI: 10.1007/s11284-006-0074-0

Rist L, Moen J. 2013. Sustainability in forest management and a new role for resilience thinking. Forest Ecology and Management 310: 416-427. DOI: 10.1016/j.foreco.2013.08.033

Santana VM, Alday JG, Baeza MJ. 2014. Effects of fire regime shift in Mediterranean Basin ecosystems: Changes in soil seed bank composition among functional types. Plant Ecology 215: 555-566. DOI: 10.1007/s11258-014-0323-1

Scheffer M, Bascompte J, Brock WA, Brovkin V, Carpenter SR, Dakos V, Held H, van Nes EH, Rietkerk M, Sugihara G. 2009. Early-warning signals for critical transitions. Nature 461: 53-9. DOI: $10.1038 /$ nature 08227 
Schneider F, Rist S. 2014. Envisioning sustainable water futures in a transdisciplinary learning process: combining normative, explorative, and participatory scenario approaches. Sustainability science 9: 463-481

Schwilch G, Bachmann F, Liniger H. 2009. APPRAISING AND SELECTING CONSERVATION MEASURES TO MITIGATE DESERTIFICATION AND LAND DEGRADATION BASED ON STAKEHOLDER PARTICIPATION AND GLOBAL BEST PRACTICES. Land Degradation and Development 20: 308-326. DOI: 10.1002/ldr

Schwilch G, Bachmann F, Valente S, Coelho C, Moreira J, Laouina A, Chaker M, Aderghal M, Santos P, Reed MS. 2012. A structured multi-stakeholder learning process for Sustainable Land Management. Journal of environmental management 107: 52-63. DOI: 10.1016/j.jenvman.2012.04.023

Schwilch G, Bestelmeyer BT, Bunning S, Critchley W, Herrick J, Kellner K, Liniger H p. H, Nachtergaele F, Ritsema C j., Schuster B, Tabo R, van Lynden G, Winslow M. 2011. Experiences in monitoring and assessment of sustainable land management. Land Degradation \& Development 22: 214-225. DOI: 10.1002/ldr.1040

Schwilch G, Liniger H, Hurni H. 2013. Sustainable Land Management (SLM) Practices in Drylands: How Do They Address Desertification Threats? Environmental Management 54: 983-1004. DOI: $10.1007 / \mathrm{s} 00267-013-0071-3$

Seidl R, Spies TA, Peterson DL, Stephens SL, Hicke JA. 2016. Searching for resilience: Addressing the impacts of changing disturbance regimes on forest ecosystem services. Journal of Applied Ecology 53: 120-129. DOI: 10.1111/1365-2664.12511

Sporton D. 2007. ANALYSING RESILIENCE IN DRYLAND AGRO-ECOSYSTEMS: A CASE STUDY OF THE MAKANYA CATCHMENT IN TANZANIA OVER THE PAST 50 YEAR. Land Degradation and Development 18: 680-696. DOI: 10.1002/ldr.807

Tabara JD, Chabay I. 2013. Coupling Human Information and Knowledge Systems with socialecological systems change: Reframing research, education, and policy for sustainability. Environmental Science \& Policy 28: 71-81. DOI: 10.1016/j.envsci.2012.11.005

Tongway DJ, Hindley NL. 2004. Landscape Function Analysis. Landscape 2614-2614. DOI: 10.1016/S0022-3913(12)00047-9

Turner MG. 2010. Disturbance and landscape dynamics in a changing world. Ecology 91: 2833-2849. DOI: $10.1890 / 10-0097.1$

Valdecantos A, Vallejo R V., Baeza MJ, Bautista S, Matthijs B, Cristoforou M, Daliakopoulos IN, Gonzalez-Pelayo O. 2016. CASCADE Report 13-Report on the restoration potential for preventing and reversing regime shifts. Paterna (Spain)

Vallejo R V., Arianoutsou M, Moreira F. 2012. Post-Fire Management and Restoration of Southern European Forests. Post-fire forest management in southern Europe: a COST action for gathering and disseminating scientific knowledge. Springer Netherlands: Dordrecht. DOI: 10.1007/978-94-007-2208-8

Walker B, Carpenter S, Anderies J, Abel N, Cumming G, Janssen M, Lebel L, Norberg J, Peterson GD, Pritchard R, ABSTRACT. 2010. Resilience Management in Social-ecological Systems: a Working Hypothesis for a Participatory Approach. Ecology and Society 15: 13. DOI: 14

Walker B, Holling CS, Carpenter SR, Kinzig A. 2004. Resilience, Adaptability and Transformability in Social - ecological Systems. Ecology and Society 9: 5. DOI: 10.1103/PhysRevLett.95.258101

Walker B, Meyers JA. 2004. Thresholds in ecological and social-ecological systems: A developing 
database. Ecology and Society 9: 3. DOI: 3

Walker BH (Brian H, Salt D (David A. 2012. Resilience practice: building capacity to absorb disturbance and maintain function. Island Press

Wilson GA. 2017. "Constructive tensions" in resilience research: Critical reflections from a human geography perspective. Geographical Journal. DOI: 10.1111/geoj.12232

WOCAT. 2008. Questionnaire on SLM technologies (Basic). A Framework for the evaluation of sustainable land management practices (revised). Centre for Development and Environment, Institute of Geography, University of Bern, Bern.: Bern

Zdruli P. 2014. Land resources of the Mediterranean: Status, pressures, trends and impacts on future regional development. Land Degradation and Development 25: 373-384. DOI: $10.1002 / \mathrm{ldr} .2150$
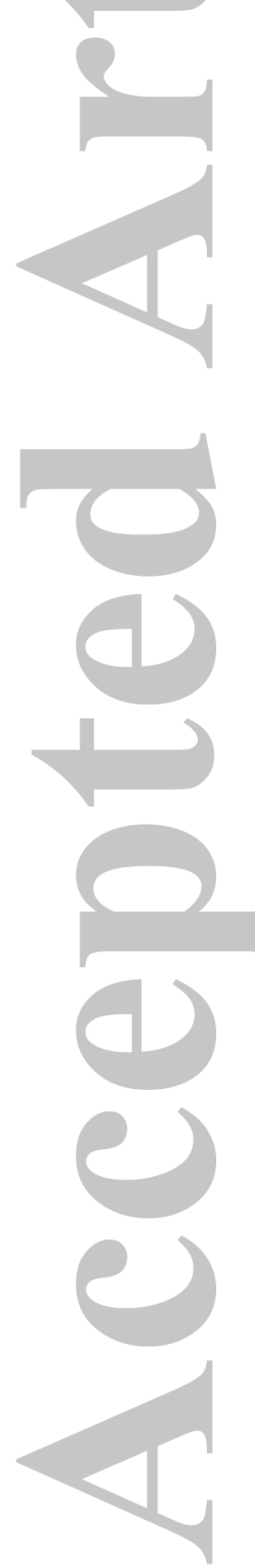
Table 1. Description of the variables considered in the resilience index and examples of high and low values

\begin{tabular}{|c|c|c|c|}
\hline Variable & Description & Low values & High values \\
\hline $\begin{array}{l}\text { Impact of } \\
\text { disturbances } \\
\left(D_{j}\right)\end{array}$ & $\begin{array}{l}\text { Impact of the } \\
\text { disturbance on } \\
\text { important } \\
\text { ecosystem } \\
\text { services }\end{array}$ & $\begin{array}{l}\text { The disturbance reduces the supply } \\
\text { of few ecosystem services where } \\
\text { many are considered important. } \\
\text { E.g. Pine disease outbreak } \\
\text { (nematodes) reduces timber } \\
\text { production in a forest considered } \\
\text { important also for biodiversity, } \\
\text { landscape value, and greenhouse } \\
\text { gas absorption }\end{array}$ & $\begin{array}{l}\text { The disturbance reduces the supply of } \\
\text { the few ecosystem services } \\
\text { considered important, or impacts } \\
\text { multiple ecosystem services. E.g. fire } \\
\text { damages or destroys the trees in a } \\
\text { forest stand considered important } \\
\text { only for timber production }\end{array}$ \\
\hline $\begin{array}{l}\text { Prevention } \\
\left(p_{i, j}\right)\end{array}$ & $\begin{array}{l}\text { Influence of the } \\
\text { LMP in } \\
\text { increasing or } \\
\text { reducing the } \\
\text { frequency and } \\
\text { intensity of a } \\
\text { disturbance }\end{array}$ & $\begin{array}{l}\text { The LMP increases the frequency } \\
\text { of the disturbance. E.g. Pine } \\
\text { afforestation increases likelihood } \\
\text { of fires }\end{array}$ & $\begin{array}{l}\text { The LMP reduces frequency or } \\
\text { intensity of the disturbance. E.g. } \\
\text { Selective clearing reduces flammable } \\
\text { biomass decreasing fire intensity }\end{array}$ \\
\hline Mitig & $\begin{array}{l}\text { Influence of the } \\
\text { LMP in } \\
\text { increasing or } \\
\text { reducing the } \\
\text { degradation } \\
\text { caused by a } \\
\text { disturbance }\end{array}$ & $\begin{array}{l}\text { The LMP increases the damage } \\
\text { caused by the disturbance. E.g. } \\
\text { limiting grazing animals' } \\
\text { movement during drought } \\
\text { increases damage to vegetation } \\
\text { suffering from drought }\end{array}$ & $\begin{array}{l}\text { The LMP reduces the damage caused } \\
\text { by the disturbance. E.g. Planting } \\
\text { shrubs on terraces reduces speed of } \\
\text { surface water, decreasing damages } \\
\text { caused by floods }\end{array}$ \\
\hline $\begin{array}{l}\text { Reco } \\
\left(v_{i, j}\right)\end{array}$ & $\begin{array}{l}\text { Influence of the } \\
\text { LMP in } \\
\text { increasing or } \\
\text { reducing the } \\
\text { speed of the } \\
\text { ecosystem's } \\
\text { recovery after a } \\
\text { disturbance }\end{array}$ & $\begin{array}{l}\text { The LMP prevents or slows down } \\
\text { recovery of the ecosystem. E.g. } \\
\text { logging after a fire damages the } \\
\text { seeds located in the soil (seed } \\
\text { bank), preventing the growth of } \\
\text { new trees }\end{array}$ & $\begin{array}{l}\text { The LMP speeds up or facilitates } \\
\text { recovery of the ecosystem. E.g. carob } \\
\text { plantation improves soil fertility and } \\
\text { reduces erosion after a fire, } \\
\text { facilitating recovery of vegetation }\end{array}$ \\
\hline Res & $\begin{array}{l}\text { Effectiveness of } \\
\text { the LMP after } \\
\text { the occurrence } \\
\text { of a disturbance }\end{array}$ & $\begin{array}{l}\text { The LMP is as effective after the } \\
\text { disturbance as it was before. E.g. } \\
\text { protection of carob trunks after a } \\
\text { drought }\end{array}$ & $\begin{array}{l}\text { The LMP is not effective after a } \\
\text { disturbance or effects negatively the } \\
\text { functioning of the ecosystem. E.g. } \\
\text { planted shrubs die during a drought, } \\
\text { increasing the flammable biomass } \\
\text { and thus the risk of fire }\end{array}$ \\
\hline
\end{tabular}


Table 2. Main features of the land management systems studied derived from section 1 of the Resilience Assessment Tool (Appendix S2)

\begin{tabular}{|c|c|c|c|c|}
\hline Study site & $\begin{array}{l}\text { Environm } \\
\text { ent }\end{array}$ & Land management objective & Land management practices & $\begin{array}{l}\text { Main land } \\
\text { managers }\end{array}$ \\
\hline $\begin{array}{l}\text { Conservati } \\
\text { on logging } \\
\text { (Por_1) }\end{array}$ & $\begin{array}{l}\text { Sub-humid } \\
\text { pine forest }\end{array}$ & $\begin{array}{l}\text { Minimizing impact of logging } \\
\text { operations on pine recruitment } \\
\text { in burnt pine forests }\end{array}$ & Post-fire conservation logging & $\begin{array}{l}\text { Company/ } \\
\text { Government } \\
\text { employees }\end{array}$ \\
\hline $\begin{array}{l}\text { Traditional } \\
\text { logging } \\
\text { (Por_2) }\end{array}$ & $\begin{array}{l}\text { Sub-humid } \\
\text { pine forest }\end{array}$ & $\begin{array}{l}\text { Maximizing wood extraction } \\
\text { in burnt pine forests }\end{array}$ & Post-fire traditional logging & $\begin{array}{l}\text { Company/ } \\
\text { Government } \\
\text { employees }\end{array}$ \\
\hline \multirow[t]{2}{*}{$\begin{array}{l}\text { Restored } \\
\text { shrubland } \\
\text { (Spa_1) }\end{array}$} & \multirow[t]{2}{*}{$\begin{array}{l}\text { Arid } \\
\text { shrub-land }\end{array}$} & \multirow[t]{2}{*}{$\begin{array}{l}\text { Restoring soil fertility and } \\
\text { combating desertification in } \\
\text { degraded shrubland }\end{array}$} & $\begin{array}{l}\text { Plantation of semi-arid woody } \\
\text { species with micro- } \\
\text { catchments } \\
\text { Plantation of diverse semi-arid } \\
\text { woody species }\end{array}$ & \multirow[t]{2}{*}{$\begin{array}{l}\text { Company/ } \\
\text { Governmen } \\
\text { employees }\end{array}$} \\
\hline & & & $\begin{array}{l}\text { Plantation of semi-arid woody } \\
\text { species on terraces }\end{array}$ & \\
\hline $\begin{array}{l}\text { Restored } \\
\text { forest } \\
(\text { Spa_2) }\end{array}$ & $\begin{array}{l}\text { Semi-arid } \\
\text { pine forest }\end{array}$ & $\begin{array}{l}\text { Conserving landscape, } \\
\text { preventing soil erosion and } \\
\text { reducing fire risk in pine forest }\end{array}$ & $\begin{array}{l}\text { Selective forest clearing } \\
\text { Cleared strip network system } \\
\text { (firebreaks) } \\
\text { Afforestation with Pinus } \\
\text { halepensis after fire }\end{array}$ & $\begin{array}{l}\text { Small-scale } \\
\text { land users }\end{array}$ \\
\hline \multirow{2}{*}{$\begin{array}{l}\text { Diversified } \\
\text { shrubland } \\
\text { (Spa_3) }\end{array}$} & \multirow[t]{2}{*}{$\begin{array}{l}\text { Semi-arid } \\
\text { shrub-land }\end{array}$} & \multirow[t]{2}{*}{$\begin{array}{l}\text { Increasing resilience to fire } \\
\text { and biodiversity in shrubland }\end{array}$} & $\begin{array}{l}\text { Clearing of fire-prone seeder } \\
\text { species. }\end{array}$ & \multirow{2}{*}{$\begin{array}{l}\text { Company/ } \\
\text { Governmen } \\
\text { employees }\end{array}$} \\
\hline & & & $\begin{array}{l}\text { Planting of resprouter shrubs } \\
\text { and trees }\end{array}$ & \\
\hline $\begin{array}{l}\text { Seasonal } \\
\text { pasture } \\
(\text { Ita_1) }\end{array}$ & $\begin{array}{l}\text { Humid } \\
\text { grassland } \\
\text { with } \\
\text { shrubs }\end{array}$ & $\begin{array}{l}\text { Regulating grazing and } \\
\text { preventing damage from wild } \\
\text { boars in pastures }\end{array}$ & $\begin{array}{l}\text { Metallic fences to regulate } \\
\text { grazing }\end{array}$ & $\begin{array}{l}\text { Small-scale } \\
\text { land users }\end{array}$ \\
\hline $\begin{array}{l}\text { Silvo- } \\
\text { pastoral } \\
\text { system } \\
\text { (Gre_1) }\end{array}$ & $\begin{array}{l}\text { Semi-arid } \\
\text { shrubland }\end{array}$ & $\begin{array}{l}\text { Restoring vegetation and } \\
\text { diversifying income in shrub } \\
\text { dominated pastures }\end{array}$ & $\begin{array}{l}\text { Grazing land afforestation } \\
\text { with carob trees }\end{array}$ & $\begin{array}{l}\text { Small-scale } \\
\text { land users }\end{array}$ \\
\hline $\begin{array}{l}\text { Extensive } \\
\text { grazing } \\
\text { (Cyp_1) }\end{array}$ & $\begin{array}{l}\text { Arid } \\
\text { Shrub-land }\end{array}$ & $\begin{array}{l}\text { Reducing degradation from } \\
\text { overgrazing in shrub } \\
\text { dominated pasture }\end{array}$ & $\begin{array}{l}\text { Planting carob and olive trees } \\
\text { to prevent erosion }\end{array}$ & $\begin{array}{l}\text { Small-scale } \\
\text { land users }\end{array}$ \\
\hline
\end{tabular}


Table 3. Land management practices identified grouped by type.

\begin{tabular}{lll}
\hline Type of land management & Land management practice & Study site \\
\hline Clearing of vegetation & Post-fire conservation logging & Por_1 \\
& Post-fire traditional logging & Por_2 \\
& Selective forest clearing & Spa_2 \\
& Cleared strip network system (firebreaks) & Spa_3 \\
& Clearing of fire-prone seeder species. & Ita_1 \\
Grazing management & Metallic fences to regulate grazing & Gre_1 \\
& Controlled grazing in spring months & Spa_1 \\
Planting of shrubs & Plantation of semi-arid woody species with micro-catchments & Spa_1 \\
& Spatially diverse plantation of diverse semi-arid woody species & Spa_1 \\
& Plantation of semi-arid woody species on terraces & Spa_3 \\
& Planting of resprouter shrubs and trees & Spa_2 \\
Planting of trees & Afforestation with Pinus halepensis after fire & Gre_1 \\
& Grazing land afforestation with carob trees & Cyp_1 \\
& Planting carob and olive trees to prevent erosion & Cyp_1 \\
Other & Carob tree protection from rats & Cyp_1 \\
\hline
\end{tabular}


Table 4. Ecosystem services indicated as important by stakeholders for each study site (see Appendix S2, section 2). Selection of ecosystem services was based on a predefined list of services derived from the WOCAT method where "productive" refers mostly to provisioning services, "ecological" to regulating services, "sociocultural" to cultural services. However, stakeholders were asked to complete the list with those services they deemed important and which were not on the list. " $\mathrm{X}$ " indicates that no ecosystem services were identified as important in that category.

\begin{tabular}{|c|c|c|c|}
\hline Study site identifier & Productive Services & Ecological services & Sociocultural services \\
\hline $\begin{array}{ll}\text { Por_1 } & \text { Conservation } \\
& \text { logging }\end{array}$ & $\begin{array}{l}\text { Animal and plant productivity } \\
\text { Water (quantity and quality) for } \\
\text { human, animal, and plant } \\
\text { consumption }\end{array}$ & Reduced erosion & $\begin{array}{l}\text { Recreation (e.g. } \\
\text { tourism, sports) }\end{array}$ \\
\hline $\begin{array}{ll}\text { Por_2 } & \text { Traditional } \\
\text { logging }\end{array}$ & Animal and plant productivity & $X$ & $\begin{array}{l}\text { Cultural services (e.g. } \\
\text { maintaining traditional } \\
\text { landscape) }\end{array}$ \\
\hline $\begin{array}{l}\text { Restored } \\
\text { shrubland }\end{array}$ & $\mathrm{X}$ & $\begin{array}{l}\text { Reduced erosion } \\
\text { Above ground biodiversity } \\
\text { Protection from extreme } \\
\text { events }\end{array}$ & $\begin{array}{l}\text { Recreation (e.g. } \\
\text { tourism, sports) }\end{array}$ \\
\hline $\begin{array}{l}\text { Restored } \\
\text { forest }\end{array}$ & Animal and plant productivity & $\begin{array}{l}\text { Reduced erosion } \\
\text { Above ground biodiversity } \\
\text { Greenhouse gas } \\
\text { absorption } \\
\text { Protection from extreme } \\
\text { events }\end{array}$ & $\begin{array}{l}\text { Recreation (e.g. } \\
\text { tourism, sports) }\end{array}$ \\
\hline $\begin{array}{l}\text { Diversified } \\
\text { shrubland }\end{array}$ & $\mathrm{X}$ & $\begin{array}{l}\text { Greenhouse gas } \\
\text { absorption } \\
\text { Protection from extreme } \\
\text { events }\end{array}$ & $X$ \\
\hline $\begin{array}{l}\text { Seasonal } \\
\text { pasture }\end{array}$ & Animal and plant productivity & $X$ & $\begin{array}{l}\text { Cultural services (e.g. } \\
\text { maintaining traditional } \\
\text { landscape) }\end{array}$ \\
\hline $\begin{array}{ll}\text { - } & \text { Silvopastoral } \\
\text { system }\end{array}$ & $\begin{array}{l}\text { Animal and plant productivity } \\
\text { Land available for production }\end{array}$ & $\begin{array}{l}\text { Reduced erosion } \\
\text { Above ground biodiversity }\end{array}$ & $\begin{array}{l}\text { Cultural services (e.g. } \\
\text { maintaining traditional } \\
\text { landscape) }\end{array}$ \\
\hline $\begin{array}{cl}\text { Cyp_1 Extensive } \\
\text { grazing }\end{array}$ & Animal and plant productivity & $\begin{array}{l}\text { Reduced erosion } \\
\text { Above ground biodiversity } \\
\text { Greenhouse gas } \\
\text { absorption }\end{array}$ & $\mathrm{X}$ \\
\hline
\end{tabular}


Table 5. Impact of disturbances measured as the ratio between ecosystem services that can be decreased by a disturbance (derived from the RAT, section 4.1) and the number of ecosystem services identified as important (eq. 1), grouped by disturbance. Values close to 0 mean no permanent impact on important ecosystem services, while close to 1 means all important ecosystem services are affected. " $n$ " represents the number of study sites affected by each disturbance (out of 8).

\begin{tabular}{llll}
\hline Disturbances & Mean impact & Standard deviation & n \\
\hline & & & \\
Wildfires & 0.74 & 0.23 & 6 \\
Droughts & 0.77 & 0.22 & 5 \\
Pests/ Diseases & 0.65 & 0.34 & 4 \\
Torrential rainfalls & 0.63 & 0.14 & 2 \\
Floods & 0.25 & 0.00 & 1 \\
\hline
\end{tabular}


Table 6. Quantitative evaluation of the impact of each land management practice (LMP) to the resilience of the land management systems in relation to different disturbances, organized by study site. Impact refers to the impact of disturbances on the ecosystem services identified as important by stakeholders $D_{j}$ (eq. 1) which ranges from 0 (no impact) to 1 (all important ecosystem services are affected). The direct influence of LMPs on the resilience of land management systems $\left(I_{i, j}\right.$, eq. 2$)$ is calculated considering prevention (p), mitigation (m), and recovery (v), and ranges from -6 to $6 . \boldsymbol{r}_{i, j}$ refers to the resistance of land management to disturbances; its values can be $0,1,2$, or 3 . Resilience refers to the overall impact of LMPs on resilience calculated using eq. 3 and can range from -1 to 1 .

\section{Land management practice}

\begin{tabular}{|c|c|c|c|c|c|c|c|c|c|}
\hline $\begin{array}{l}\text { Study } \\
\text { site }\end{array}$ & Land management practice & Name & $\begin{array}{l}\text { Impact } \\
\left(D_{j}\right)\end{array}$ & $p$ & $m$ & $v$ & $I_{i, j}$ & & $R_{i, j}$ \\
\hline Por_ & Conservation logging & fires & 0.75 & -1 & 0 & -1 & -2 & 0 & -0.25 \\
\hline & Conservation logging & pests / diseases & 0.25 & -1 & 1 & 0 & 0 & 0 & 0.00 \\
\hline \multirow[t]{2}{*}{ Por_2 } & Traditional logging & fires & 1.00 & 1 & 0 & -1 & 0 & 0 & 0.00 \\
\hline & Traditional logging & pests / diseases & 1.00 & -1 & 2 & 0 & 1 & 0 & 0.17 \\
\hline \multirow{15}{*}{ Spa_1 } & Shrub plantation with catchments & droughts & 1.00 & 0 & 1 & 1 & 2 & 3 & -0.17 \\
\hline & Diverse shrub plantation & & & 0 & 1 & 1 & 2 & 3 & -0.17 \\
\hline & Shrub plantation with terraces & & & 0 & 0 & 0 & 0 & 1 & -0.17 \\
\hline & Shrub plantation with catchments & torrential rainfalls & 0.75 & 0 & 2 & 1 & 3 & 2 & 0.13 \\
\hline & Diverse shrub plantation & & & 0 & 2 & 1 & 3 & 1 & 0.25 \\
\hline & Shrub plantation with terraces & & & 0 & 2 & 1 & 3 & 2 & 0.13 \\
\hline & Shrub plantation with catchments & floods & 0.25 & 0 & 1 & 1 & 2 & 3 & -0.04 \\
\hline & Diverse shrub plantation & & & 0 & 2 & 1 & 3 & 3 & 0.00 \\
\hline & Shrub plantation with terraces & & & 0 & 2 & 1 & 3 & 3 & 0.00 \\
\hline & Selective clearing & fires & 1.00 & 2 & 2 & 1 & 5 & 1 & 0.67 \\
\hline & Fuel breaks & & & 2 & 2 & 0 & 4 & 2 & 0.33 \\
\hline & Afforestation with P. halepensis & & & -1 & 1 & 1 & 1 & 3 & -0.33 \\
\hline & Selective clearing & droughts & 0.67 & 0 & 1 & 1 & 2 & 0 & 0.22 \\
\hline & Fuel breaks & & & 0 & 0 & 0 & 0 & 1 & -0.11 \\
\hline & Afforestation & & & 0 & 1 & 1 & 2 & 3 & -0.11 \\
\hline \multirow[t]{4}{*}{ Spa_3 } & Shrub clearing & fires & 0.50 & 2 & 2 & 1 & 5 & 0 & 0.42 \\
\hline & Resprouter shrub plantation & & & 0 & 1 & 2 & 3 & 1 & 0.17 \\
\hline & Shrub clearing & droughts & 1.00 & 0 & 2 & 1 & 3 & 0 & 0.50 \\
\hline & Resprouter shrub plantation & & & 0 & 0 & 0 & 0 & 2 & -0.33 \\
\hline Ita & Fences & pests / diseases & $1.00^{-}$ & 1 & 1 & 1 & 3 & 1 & $0.33^{-}$ \\
\hline \multirow[t]{6}{*}{ Gre_1 } & Carob plantation & fires & $0.80^{-}$ & 0 & 0 & 2 & 2 & 1 & 0.13 \\
\hline & Controlled grazing & & & 1 & 2 & 1 & 4 & 2 & 0.27 \\
\hline & Carob plantation & pests / diseases & 0.50 & 1 & 1 & 1 & 3 & 2 & 0.08 \\
\hline & Controlled grazing & & & 1 & 1 & 1 & 3 & 2 & 0.08 \\
\hline & Carob plantation & droughts & 0.40 & 0 & -1 & 1 & 0 & 2 & -0.13 \\
\hline & Controlled grazing & & & 0 & -1 & 0 & -1 & 1 & -0.13 \\
\hline \multirow[t]{9}{*}{ Сур_1 } & Carob plantation & droughts & 0.75 & -1 & 1 & 1 & 1 & 1 & 0.00 \\
\hline & Tree protection & & & 0 & 1 & 1 & 2 & 0 & 0.25 \\
\hline & Fodder provision & & 0.75 & 0 & 2 & 1 & 3 & 1 & 0.25 \\
\hline & Carob plantation & fires & 0.50 & -1 & 0 & 1 & 0 & 1 & -0.08 \\
\hline & Tree protection & & & 0 & 1 & 1 & 2 & 2 & 0.00 \\
\hline & Fodder provision & & & 0 & 1 & 1 & 2 & 0 & 0.17 \\
\hline & Carob plantation & torrential rainfalls & 0.50 & 0 & 1 & 1 & 2 & 0 & 0.17 \\
\hline & Tree protection & & & 0 & 2 & 1 & 3 & 0 & 0.25 \\
\hline & Fodder provision & & & 0 & 0 & 1 & 1 & 1 & 0.00 \\
\hline
\end{tabular}

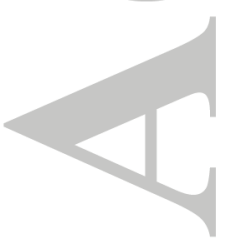




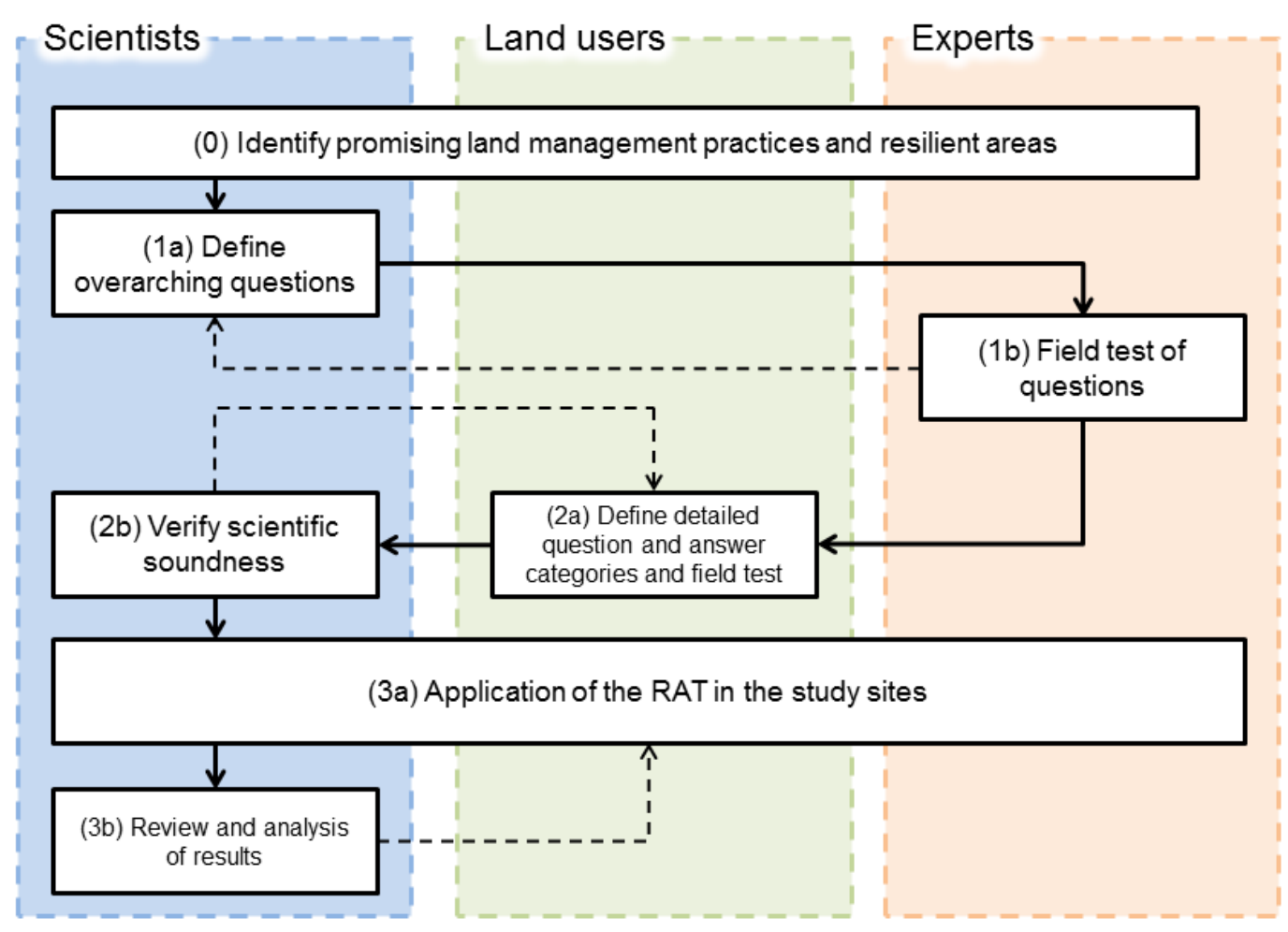

Figure 1. Design process of the Resilience Assessment Tool (RAT) and interactions with different stakeholder groups. "Experts" refers to local experts or land management advisors; "land users" includes land owners, shepherds, and forest workers. Dashed lines represent review after testing phases. Detailed description of each phase is presented in Method S1 


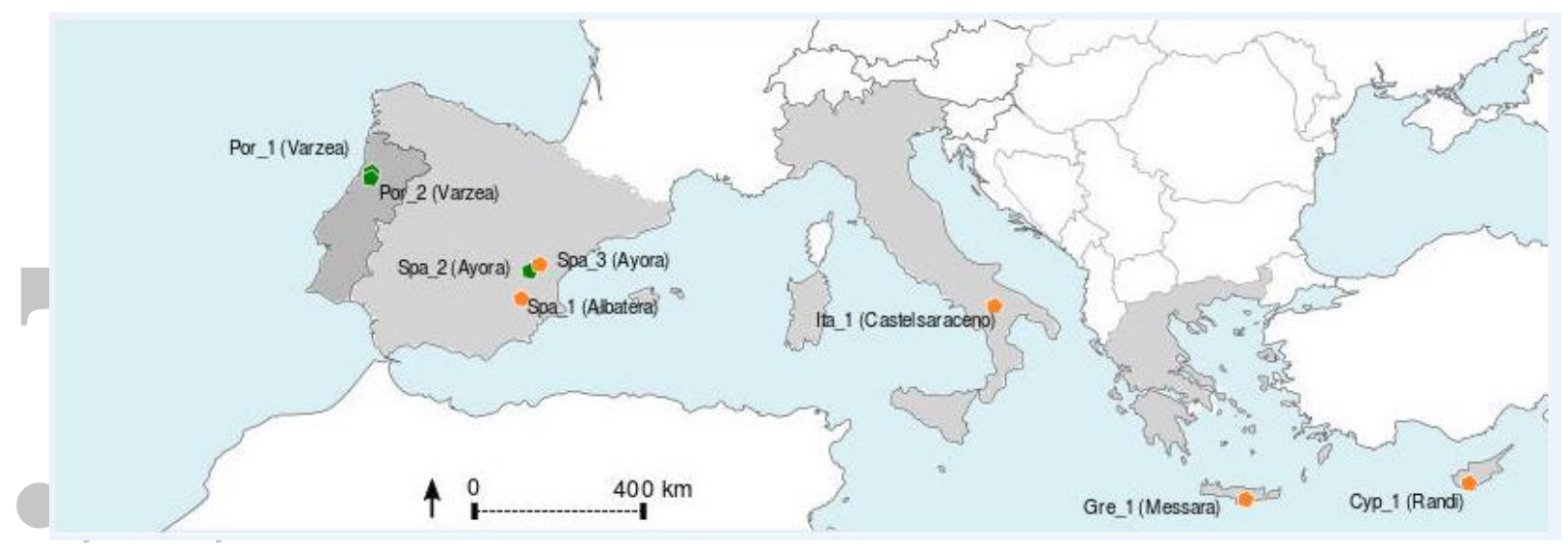

Figure 2. Location of study sites with place names in brackets. Study site countries are depicted in dark grey. Forest sites are marked in green, while rangeland sites are marked in orange.
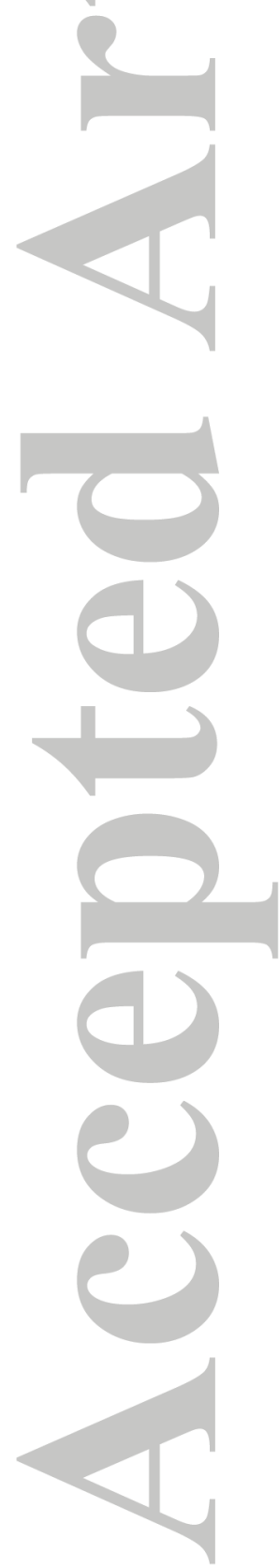


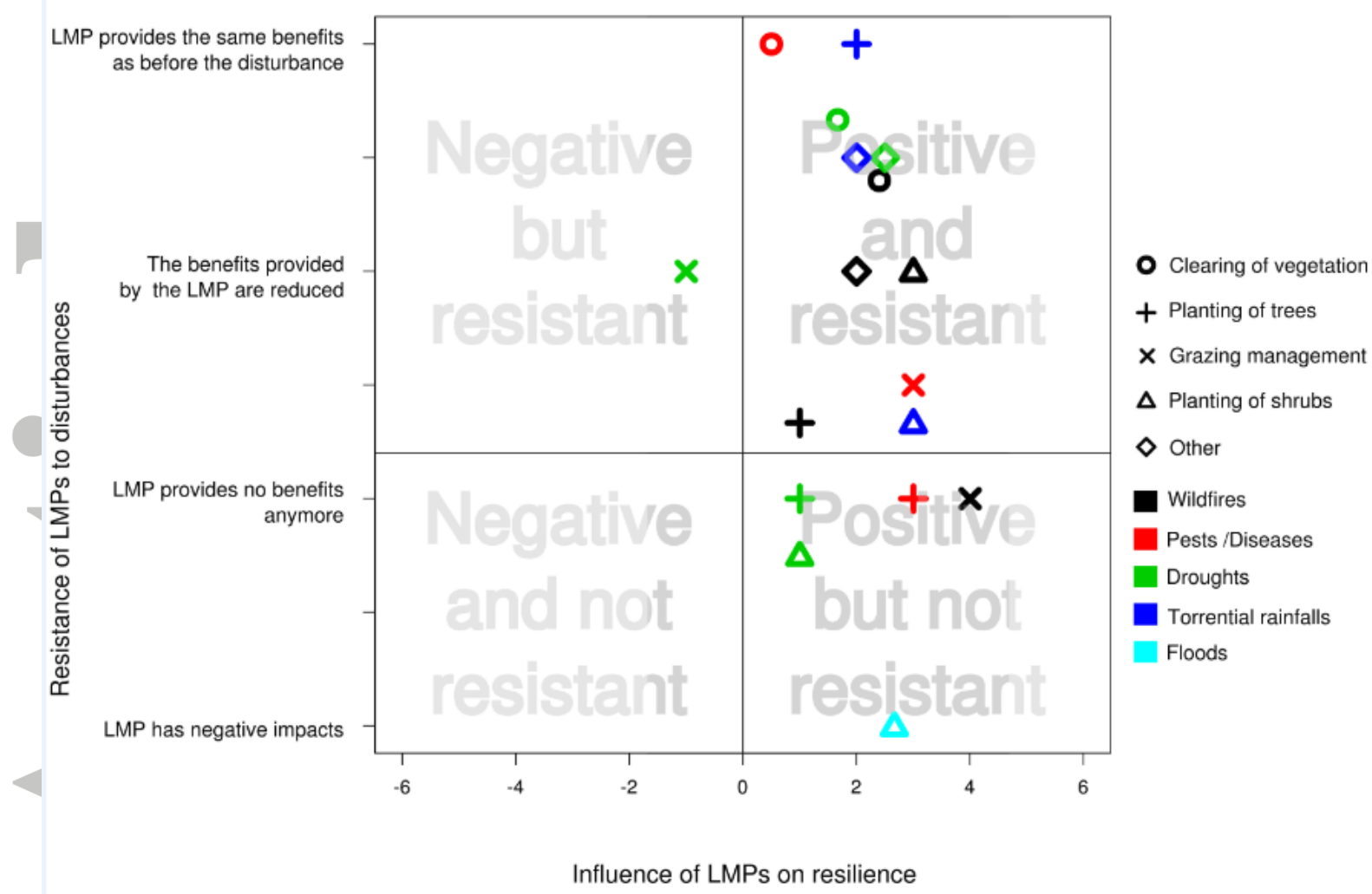

Figure 3. Average influence of land management practices (LMPs) on the disturbance (x axis; relative units) and resistance of LMPs to the disturbance (y axis) by type of practice. The shapes correspond to the different LMP types, the colour indicates the type of disturbance, and lines separate positive from negative evaluations.

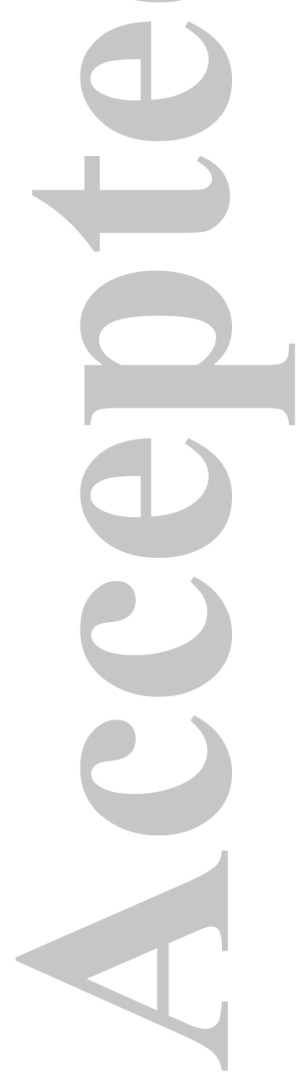


Forest systems

Restored

forest (Spa_2)

Traditional

logging (Por_2)

Conservation

logging (Por_1)

Rangeland systems

Extensive grazing (Cyp_1)

Silvopastoral system (Gre_1)

Seasonal pasture (Ita_1)

Diversified shrubland (Spa_3)

Restored

shrubland (Spa_1)

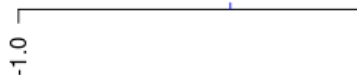

Less resilience
LMPs Ds

3

2

12

12

33

23

11

22

33

Contribution of land management to resilience

Figure 4. Contribution of land management practices (LMPs) to the resilience of each land management system. The bars range from minimum to maximum resilience values (considering all LMPs in relation to all the disturbances affecting each land management system); the dots indicate the average value. For each land management system, LMPs indicate the number of practices, and Ds indicate the number of different disturbances. 